\title{
NEURO-CUTANEOUS MELANOSIS
}

\author{
BY \\ H. FOX, J. L. EMERY, R. A. GOODBODY, and P. O. YATES \\ From the Departments of Pathology, University of Manchester, Children's Hospital, Sheffield. \\ and Southampton General Hospital
}

(RECEIVED FOR PUBLICATION FEBRUARY 17, 1964)

Combined congenital abnormalities of the skin and central nervous system are well recognized-such conditions as Sturge-Weber syndrome, tuberous sclerosis, and neurofibromatosis. A very much rarer and less well-known member of this group is neurocutaneous melanosis. A review of the published material shows that only 18 cases of this syndrome have been previously recorded. It is, therefore, thought worth while to describe another 3 examples of this rare condition occurring in young children.

\section{Case Reports}

Case 1. A white male child aged 19 months was seen in the neuro-surgical department of the Manchester Royal Infirmary. He had been a full-term normal delivery, and the mother had been well throughout th: course of the pregnancy. He was well at birth, but numerous large pigmented hairy naevi were noted in the skin of the body and limbs. Development had been normal and all the mile-stones had been passed at the normal times. When aged 16 months he had a generalized convulsion, but recovered from this and continued to appear well and to progress normally until, at the age of 19 months, he had a further single generalized convulsion. On examination at this stage the abnormal findings were the presence of numerous large pigmented skin naevi, a head circumference of 23 in. $(58 \cdot 4 \mathrm{~cm}$.), and a mild grade of papilloedema. No evidence of abnormal retinal pigmentation was seen on ophthalmoscopic examination. Myodil ventriculography showed marked dilatation of the lateral and third ventricles, and there appeared to be an obstruction of the iter at the point of its entry into the fourth ventricle. A posterior fossa decompression was performed, and it was noted at operation that the meninges overlying the cerebellum were thickened and pigmented. The underlying cerebellar cortex also appeared to be pigmented. After operation the child remained well for eight weeks, but it was then noted that he was ataxic and though he was talking well he was emitting a shrill high-pitched cry at frequent intervals. The posterior fossa decompression was tense and bulging, and a Pudenz valve was therefore inserted into the right lateral ventricle draining into the right internal jugular vein. The child then remained fairly well, apart from some degree of ataxia, for a further period of four months, when he was readmitted with increasing restlessness, ataxia, and rigidity. The posterior fossa decompression was again tense and bulging, and at operation the Pudenz valve was found to be blocked by a protein coagulum, and it was replaced. Three days after the operation the child's conscious level began to decline: he developed left-sided Jacksonian epileptiform attacks and, despite repeated ventricular taps, died at 25 months.

NECROPSY. There were no abnormal pathological findings outside of the skin and the central nervous system. In particular, no evidence of tumour was found in any other organ. The skin showed numerous large pigmented hairy naevi on the skin of the limbs, chest, trunk, back, and scalp. These varied in size, but ranged up to a maximum diameter of $6 \mathrm{~cm}$.

The dura appeared normal and showed no evidence of pigmentation, but the pia-arachnoid showed a diffusely grey coloration most marked over the right cerebra hemisphere. In addition there were numerous scattered

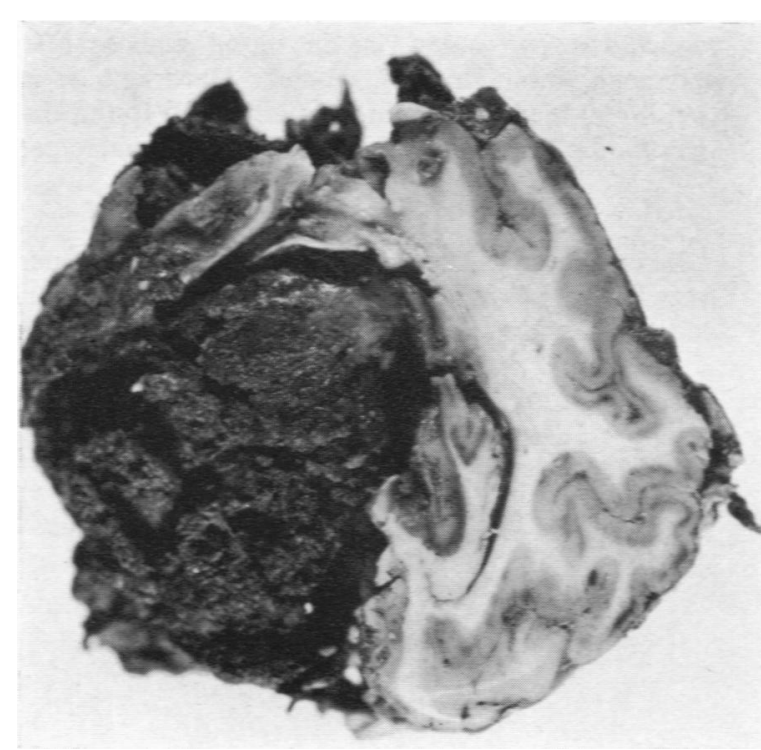

Frg. 1.-Case 1. Right occipital lobe of brain. The cerebral tissue is partially replaced by a mass of black tumour tissue. 


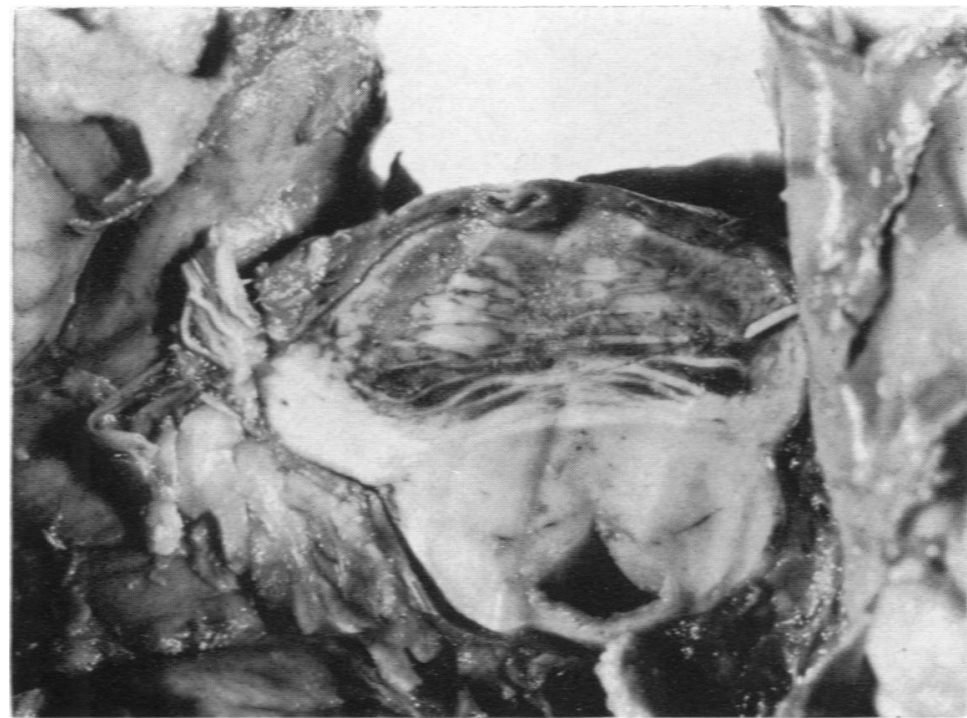

FiG. 2.-Case 1. Pons showing streaky black pigmentation of the grey matter of the reticular substance. The thickened pia-arachnoid can be seen on the ventral surface of the pons.

patches of more intense brown pigmentation, particularly over the right sylvian region, around the infundibular stalk, and over the ventral surface of the pons. The pigmented pia-arachnoid of the ventral surface of the pons was considerably thickened. On slicing the brain there was symmetrical hydrocephalus involving the lateral and third ventricles. The pigmentary change in the arachnoid extended down the sulci and involved the underlying cortical ribbon in many areas, most particularly the cortex of the right frontal lobe. There were scattered patches of pigment in the sulci and cortex of the left cerebral hemisphere and the cortical ribbon of the left occipital lobe, particularly the calcarine cortex, was heavily pigmented. The right occipital lobe and posterior portion of the right temporal lobe were replaced by a semi-necrotic, ragged, friable mass of black tumour tissue (Fig. 1). The reticular nuclei of the pons showed a remarkable picture with streaky black pigmentation of the grey matter that did not appear to be involving the white matter (Fig. 2). The substantia nigra on both sides was quite pale. On slicing the cerebellum it was seen that the pigment involved also the grey matter of the

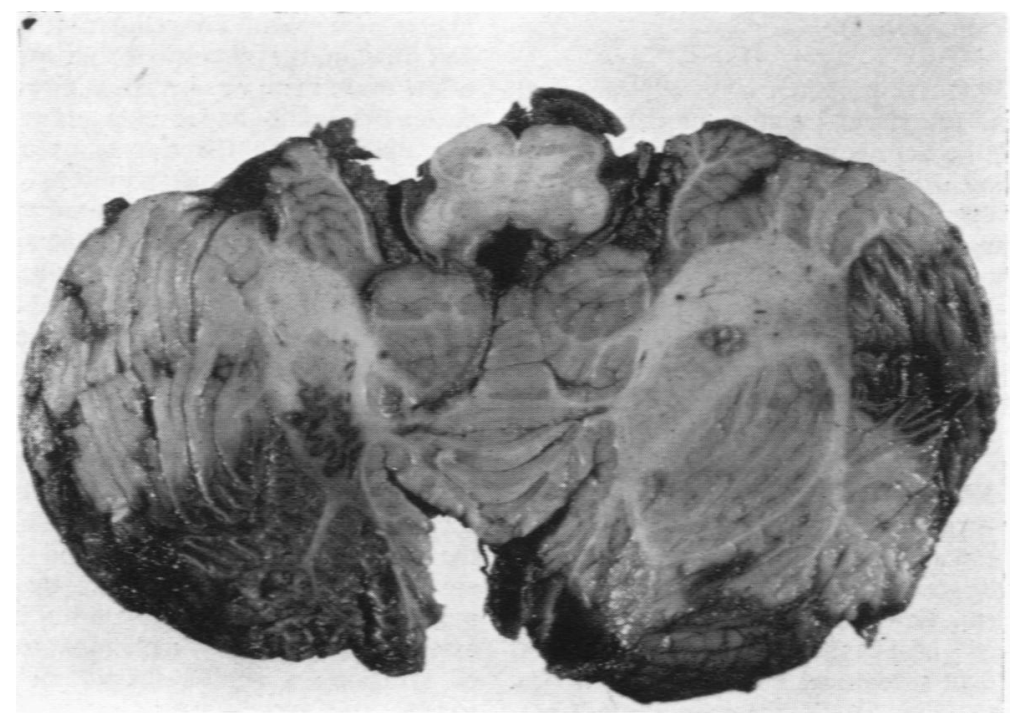

FK. 3.-Case 1. Cerebellum showing pigmentation of left dentate nuckeus. 


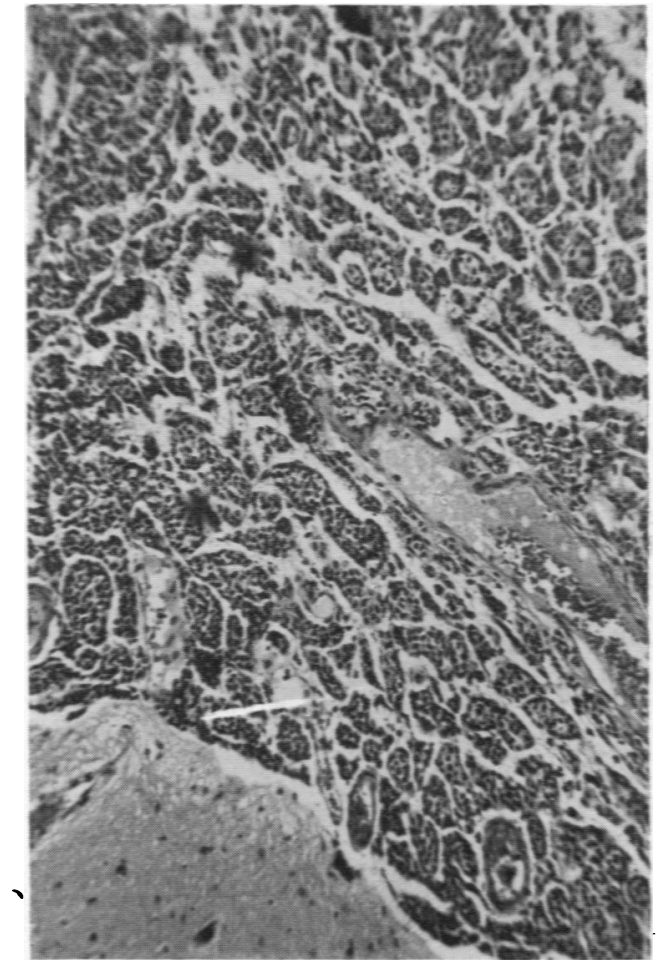

FK. 4.-Case 1. Pia-arachnoid overlying medulla. Nests of rounded malanoblasts showing a regular pattern with no pleomorphism. (H. and $E$. $\times 60)$.

cerebellar folia and picked out, in a most remarkable way, the left dentate nucleus (Fig. 3).

Histology. All the skin lesions showed the usual features of a benign intradermal pigmented naevus. In the deeper part of the dermis there was, just below the pigmented cells, some degree of proliferation of the nerve fibres and of nerve sheaths. The meninges were thickened. The dura was normal but the pia-arachnoid was infiltrated throughout by melanoblasts, many of which were pigmented. However, the degree of pigmentation varied considerably from area to area. The histological features of the cellular infiltration also varied considerably. In the pia-arachnoid of the cervical cord and medulla the melanoblasts were arranged in nests or clusters (Fig. 4). The cells were round or polygonal with large vesicular nuclei and showed little variation in size, shape, or nuclear structure. Mitotic figures were not seen in this area, and melanophores, i.e. pigment-laden macrophages, were scanty. In the meninges of the cerebral hemispheres, however, both over the actual hemispheres and on the base of the brain, the melanoblasts were closely packed in sheets and had assumed a more spindle-shaped form (Fig. 5). There was a moderate degree of variation in cellular and nuclear size and

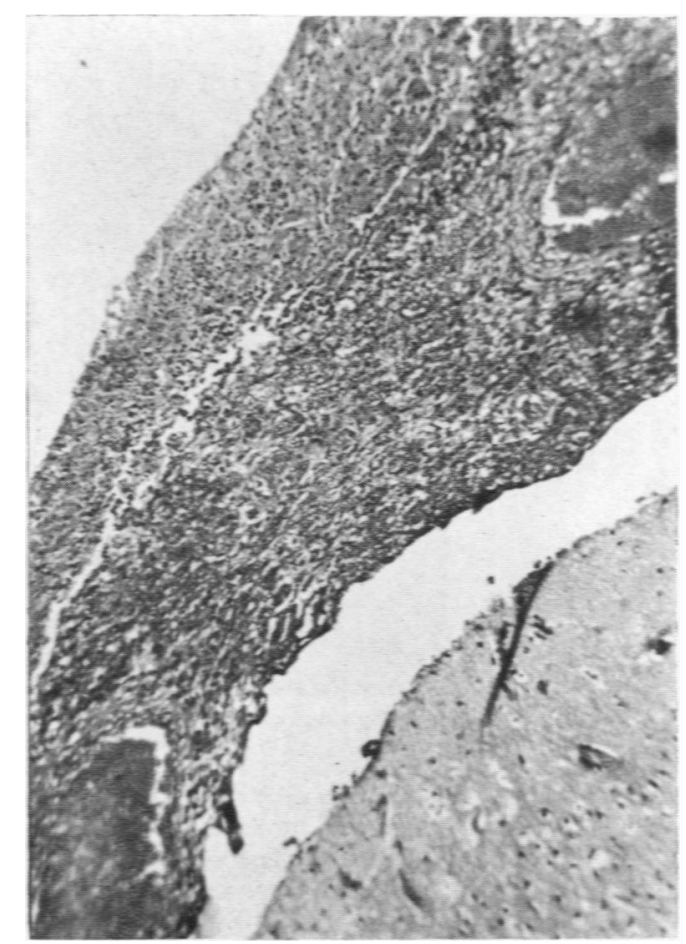

Fig. 5.-Case 1. Pia-arachnoid overlying cerebral hemisphere. Here the melanoblasts are spindle shaped. arranged in sheets. and show considerable pleomorphism. (H. and E. . 60).

melanophores were more numerous. Occasional mitotic figures were seen. The cellular infiltration extended into, and filled in, the Virchow-Robin spaces. In many areas of the brain there was invasion of the underlying cerebral cortex by spindle-shaped melanoblasts (Fig. 6). Invasion was mainly from the extensions into the perivascular spaces. Numerous melanophores were also present in the brain tissue and also appeared to derive mainly from the cells present in the perivascular spaces. It was noted that where cerebral invasion was most marked the meninges overlying this area showed the greatest degree of spindle formation and also the greatest degree of pleomorphism and increased mitotic activity. The occipital lobe tumour was formed of round or spindle cells, only very occasionally pigmented, showing considerable pleomorphism and many mitotic figures. The appearances were those of a malignant melanoma. The cerebellum showed no actual invasion by tumour cells, the pigmentation of the cortex and dentate nucleus being solely due to an infiltration by heavily pigmented melanophores. The grey matter of the pons also showed extensive infiltration by melanophores but occasional foci of invasion by spindle-shaped melanoblasts from the perivascular spaces were also seen. In the pons, the melanophore infiltration was almost entirely confined to 


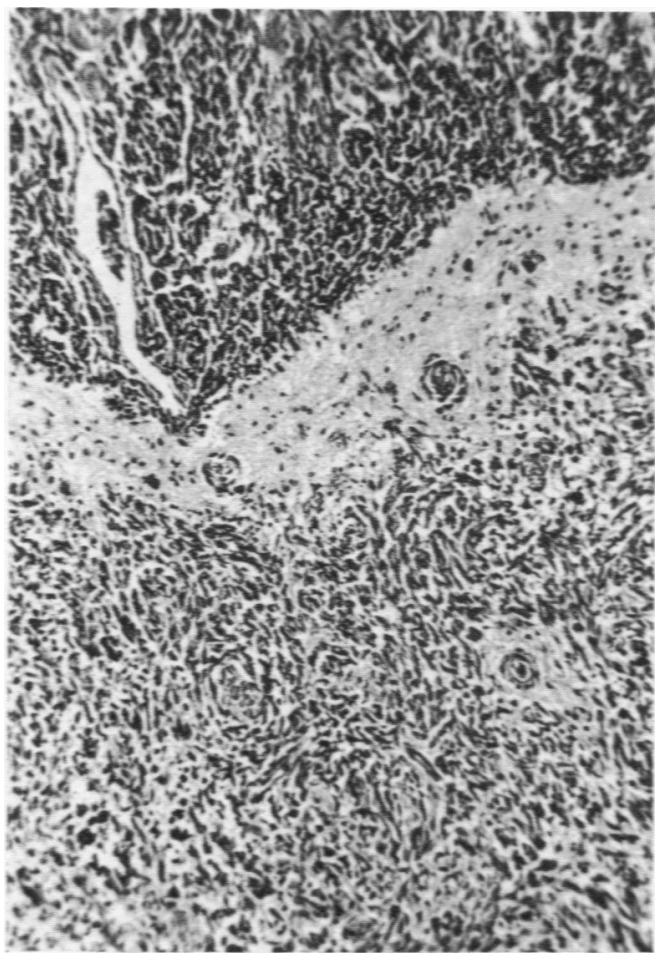

FKG. 6.-Case 1. Pia-arachnoid and underlying cerebral cortex. There is infiltration of the cerebral tissue by spindle-shaped melanoblasts. (H. and E. $\times 60$ ).

the grey matter, the white matter being curiously free from such cells. Apart from this pigmentation and infiltration by tumour cells the brain was essentially normal. The cerebellum did, however, show some areas of microgyria.

Case 2. A white male child, aged 12 months at death, was quite well until two days before death when he was said to have started vomiting. He died one hour after admission having developed generalized epileptic convulsions. From birth he had had multiple pigmented hairy naevi, the largest of which covered most of the skin of the upper half of the back (Fig. 7); there were a number of smaller similar naevi on trunk and limbs. Normal progress in growth and development had been made with no evidence of neurological disease until the terminal convulsions.

NECROPSY. The organs of the body showed no significant pathological change. The meninges, both dura and arachnoid, appeared normal, and no unusual pigmentation was seen. Slicing of the brain, however, revealed a deep blackish pigmentation which was almost confined to grey matter. This was seen especially in a number of brain-stem nuclei and the reticular grey matter of the pons. The dentate and roof nuclei of the cerebellum, one amygdaloid nucleus, and parts of the thalamus were all heavily pigmented. A few areas of cerebral cortex showed pigment, and the white matter was involved only where close to affected grey masses, such as the dentate nuclei of the cerebellum.

Histologically the pigment everywhere was either free or within macrophages and was usually arranged along capillaries though other small vessels were sometimes involved. In some areas the pia-arachnoid appeared unusually cellular, and although some of this was fibroblastic many of the extra cells could have been naevoid. They showed no evidence of active growth nor was there any detectable pigment secretion. The skin lesions showed the typical appearance of a pigmented dermal naevus with no evidence of active growth.

Case 3. This boy was born at 40 weeks gestation weighing $10 \mathrm{lb}$. 1 oz. (4563 g.) following a normal pregnancy to normal parents.

He was said to have had a large head at birth, and there were numerous skin naevi, showing varying degrees of pigmentation and also varying amounts of hair. He smiled at 4 months, sat supported at 7 months, and walked at 1 year, but was backward compared with the single elder sib. When he was 4 months old, three large pedunculated tumours were removed from the buttocks: the histology was that of the common pigmented naevus mixed with fatty cells and abnormal nerve trunks.

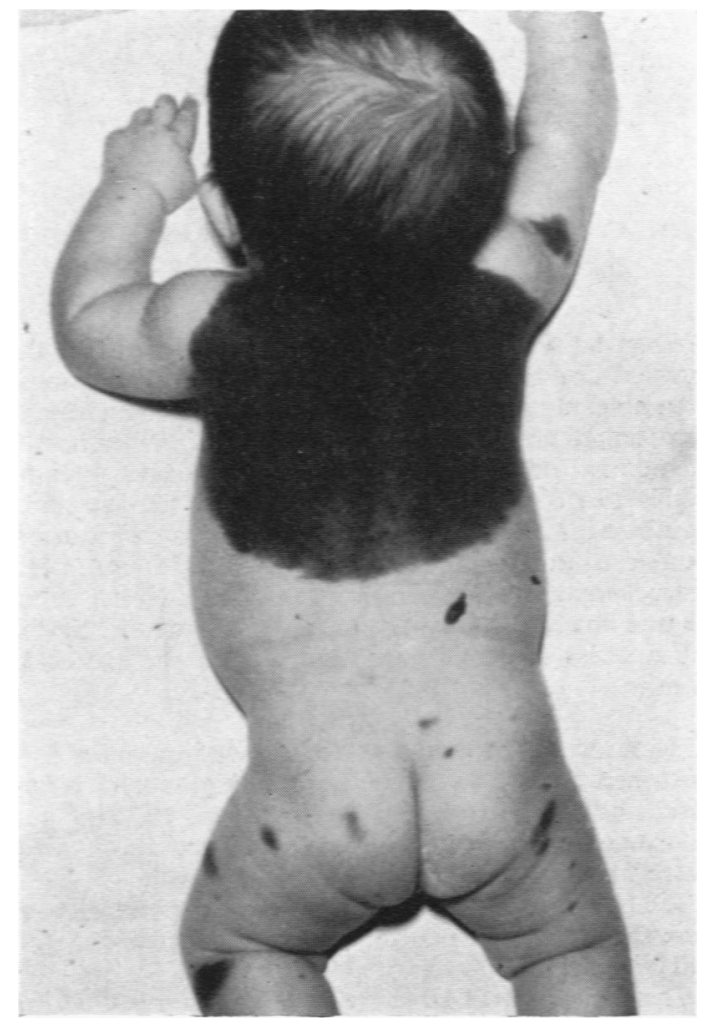

Fig. 7.-Case 2. Photograph of child showing extensive pigmented skin naevi. 


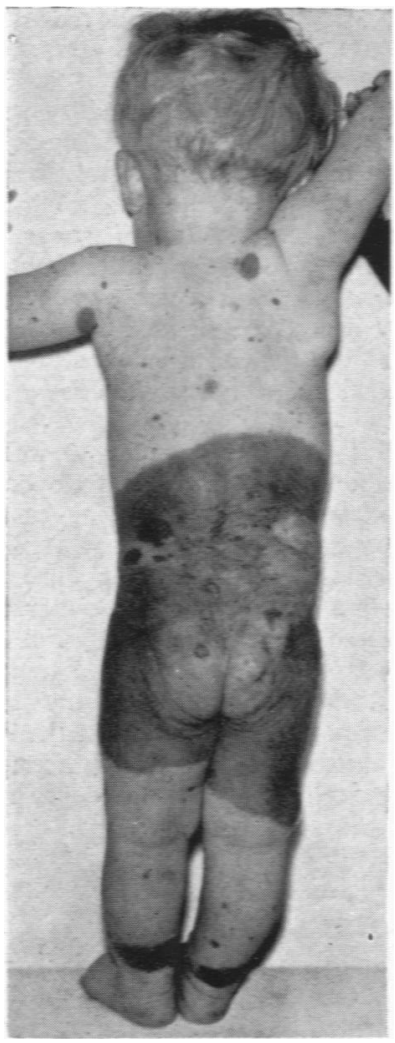

FK. 8.-Case 3. Photograph of the child showing typical hairy mole covering the trunk area.

When he was 5 months old he was admitted to the Sheffield Children's Hospital with a history of occasional screaming, almost as if he had headache, of being listless, of ceasing to play and wanting to lie down. When he was 13 months old he stopped walking, and later became unable to sit up. He was readmitted at the age of 17 nonths with a history of recurrent spasms in his arms. He had a head circumference of 22 in. $(56 \mathrm{~cm}$.). His hydrocephalus was treated by insertion of a Holter valve. He was finally admitted at the age of 22 months, having had a series of convulsions, and died at the age of 23 months.

NeCROPSY. The child's external appearances are illustrated by Fig. 8 . There were multiple moles, many raised and hairy, varying in size from $1 \mathrm{~cm} .^{2}$ to $3 \mathrm{~cm} .^{2}$ and an extensive naevoid involvement of the trunk area. There was moderate enlargement of the head.

The body cavities were free from gross pigmentation, as were the abdominal viscera. There was chronic cystitis and bilateral hydro-ureter.

The brain showed large blackened areas most marked over the posterior aspects of both hemispheres, the bases of the occipital poles, and the cerebellum. The base of the brain was completely filled by black material looking a little like old blood clot, but darker, and the whole of the spinal canal was filled with solid material which on section looked not unlike 'black pudding'. The meninges over the cerebral hemispheres were relatively unaffected. There was bilateral dilatation of the cerebral ventricles with many dark areas of up to $2 \mathrm{~cm}$. in diameter on the ventricle walls.

Histology. The only viscera showing cells which appeared to be naevus cells were the testes and parts of the bladder wall. Some of these cells appeared to contain melanin.

The skin lesions showed a rather bizarre picture but with no significant difference from the pictures seen in benign moles and naevi that frequently occur in isolation and are seen as routine surgical biopsies. No areas appeared to be malignant.

Multiple sections were taken throughout of the brain and spinal cord. There was very great variation in the pigment load of cells in different areas. This can be seen well in the photograph (Fig. 9) showing part of a transverse section of the spinal cord. The naevus cells did not appear to be directly infiltrating the brain tissue and occurred as large sheets in the surrounding connective tissue and in the connective tissue of the perivascular spaces. The typical picture of the surface of the brain is illustrated in Fig. 10, and the way in which almost isolated pigment-bearing cells could be found in associa-

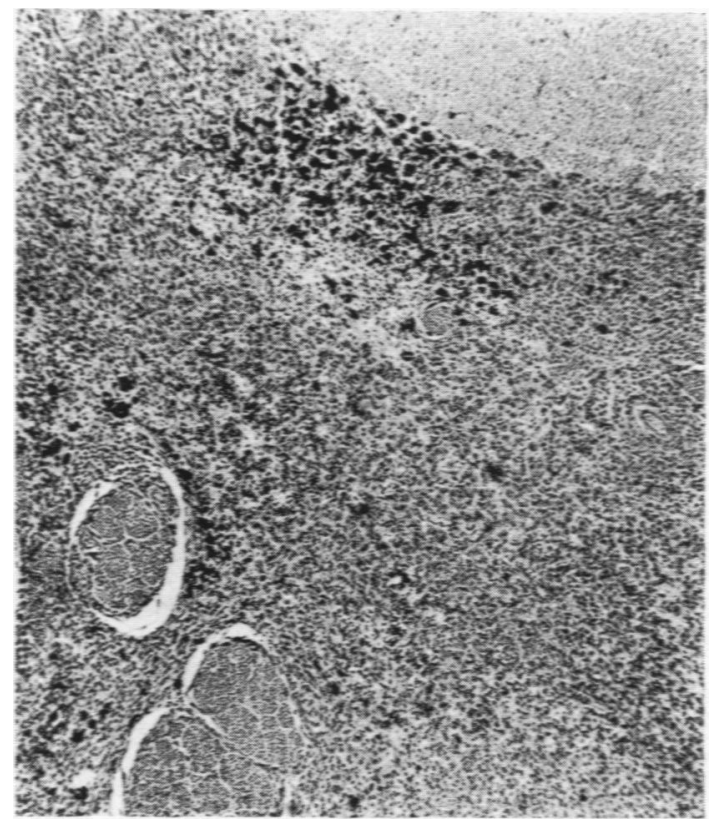

Fig. 9.- Case 3. Photograph of the cell mass around the spinal cord. Part of the spinal cord is shown in the top part of the section and nerve roots can be seen in the lower left hand corner. The whole of the intervening space is filled with masses of naevus cells, and the variation in the localization of the deeply pigmented cells can well be seen. (Masson's Trichrome. $\times$ 85.) 


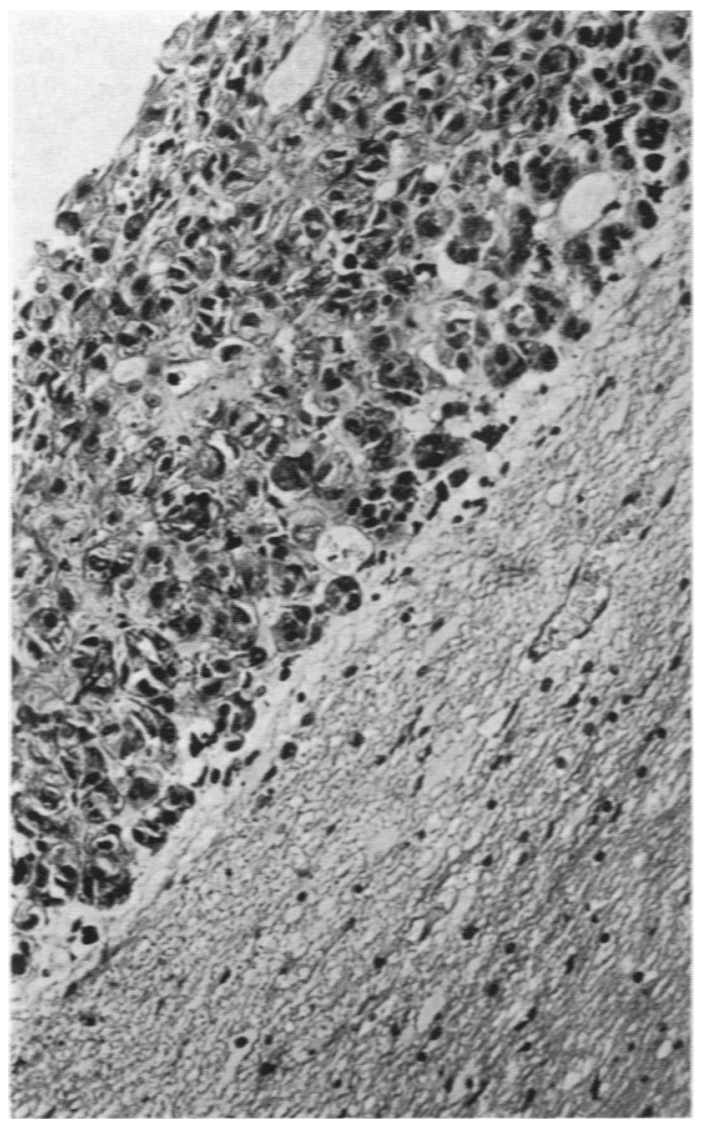

FK. 10. - Case 3. Photograph of the surface of the brain showing a layer of naevus cells on the surface. Note the absence of local infiltration of the brain. (H. and E. $\times 200$.)

tion with small blood vessels encircling neurones is illustrated in Fig. 11.

Undoubtedly death was due to the mass of naevus tissue compressing the central nervous system.

\section{Discussion}

Review of Published Cases. The syndrome of combined cutaneous and meningeal pigmentation has been given the name of "neuro-cutaneous melanosis' by Van Bogaert (1948) and the first description of such a case was recorded by Rokitansky in 1861. His patient was a 14-year-old hydrocephalic and mentally defective girl who had extensive pigmented naevi of the skin, and who was found at necropsy to have thickening and pigmentation of the pia-arachnoid due to an infiltration by pigmented cells. There was no evidence of any invasion of the underlying brain.

In the century that has elapsed since Rokitansky's

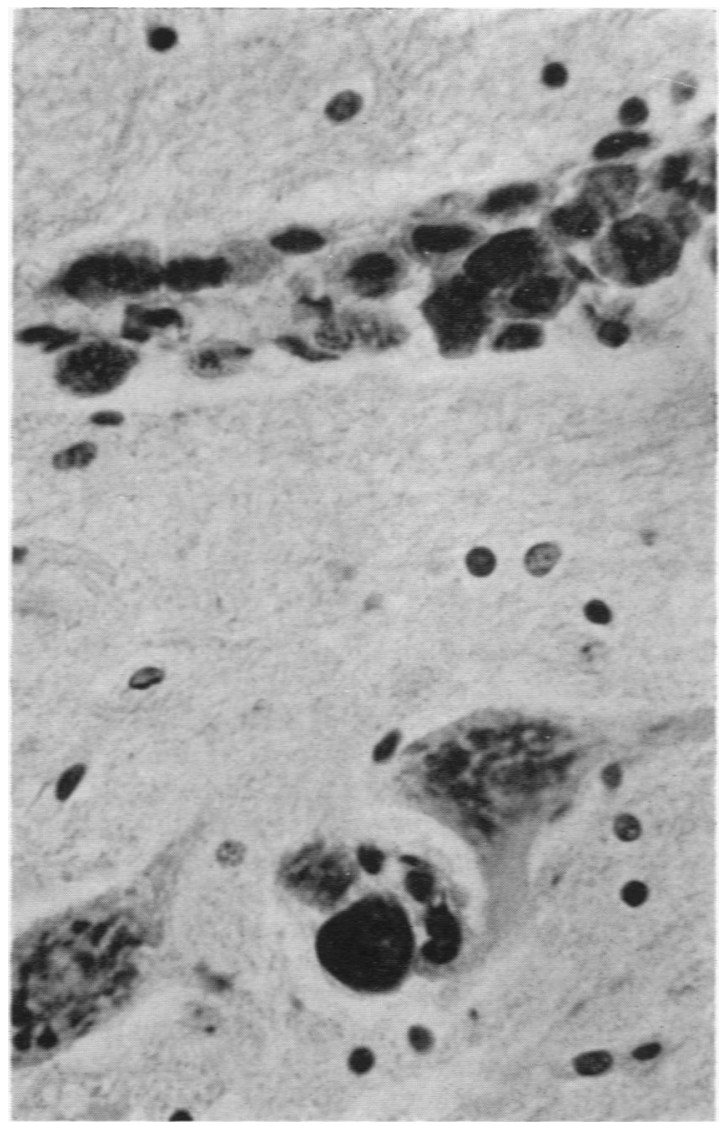

Fig. 11.-Case 3. Photograph of the ganglion cells within the spinal cord showing isolated naevus cells deeply pigmented. One lies in a small vessel virtually in contact with a ganglion cell. The others lie along a vessel paralkel to the plane of the section. (Masson's Trichrome. 700.)

original report only a further 17 cases have been recorded. These cases are detailed in the Table. All have been adequately studied at necropsy, and it can be seen that death usually occurs during infancy and childhood. Thus, only 5 of the 17 patients reached the age of 20 , and of these only 3 passed the age of 25. Three of the cases were stillbirths and a further 5 patients died during the first year of life. The sexes are equally represented and a family history of abnormal pigmentation has been noted in only one case; this being the 41-year-old man described by Van Bogaert (1948). This patient had a strong family history of miltiple skin naevi but he was the only member of this family who was known to have abnormal meningeal pigmentation. In two patients (Björnboe, 1934; Berblinger, 1915) there was an associated neurofibromatosis, and in one case 
TABLE

REPORTED CASES OF NEURO-CUTANEOUS MELANOSIS

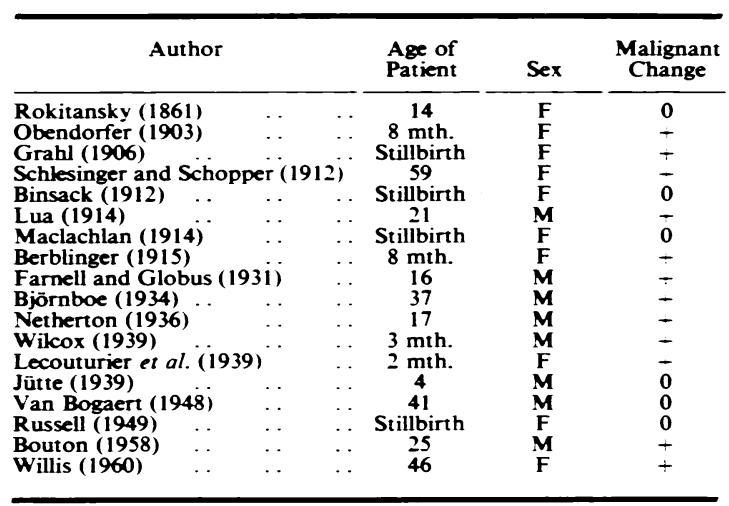

(Wilcox, 1939) the melanosis was associated with pial telangectasis. All the patients (with one exception) had numerous pigmented skin naevi. These varied in number; but, for example, Berblinger (1915) was able to count 190 separate skin naevi in his patient. A curious but typical feature is the frequency with which the patients have a large 'bathing trunk' naevus involving the skin of the lower abdomen, the buttocks and the upper part of the thighs. As almost every individual can boast of several small pigmented cutaneous naevi, cases have not been included in this series unless the naevi were either extremely large or unusually numerous. The single exception to this is the patient described by Bouton (1958), who had no localized skin naevi but whose skin showed a marked generalized brownish pigmentation similar to that seen in Addison's disease. Unfortunately no description of the histological features of the skin is given in this case report. Cases in which there is evidence of malignant change in any of the cutaneous naevi (e.g. Neubuerger, Daniels, and Draper, 1943) cannot be accepted as examples of neuro-cutaneous melanosis, for the possibility that the meningeal infiltration represents a secondary deposit from such a malignant skin lesion cannot be completely excluded.

In all previous cases melanoblastic infiltration of the meninges had produced macroscopic thickening and pigmentation of the pia-arachnoid. Our Case 2 did not, however, show any such appearance, although pigmentation within the brain was quite marked. Though in most cases the infiltration was diffuse the most marked areas of infiltration were usually the meninges at the base of the brain in the interpeduncular fossa and over the pons, medulla, and cerebellum. Netherton's case (1936) is unusual in that the most striking infiltration was in the pia-arachnoid of the spinal cord. The dura has been normal in all cases. Macroscopic pigmentation of the cerebral cortex has been seen in only 1 case (Wilcox, 1939), but in 7 cases (Berblinger, 1915; Farnell and Globus, 1931; Lecouturier, Ley, Titeca, and van Bogaert, 1939; Maclachlan, 1914; Grahl, 1906; Russell, 1949; Jütte, 1939) there was macroscopic pigmentation of the cerebellum and pons. The cerebellar pigmentation was in all cases most marked in the cortex, but striking pigmentation of the dentate nucleus on one or both sides was noted in 3 cases (Berblinger, 1915; Maclachlan, 1914: Lecouturier et al., 1939). Pigmentation in the pons was seen in all these 7 cases and each one showed appearances similar to that seen in Case 1, described above. The pontine pigmentation invariably appeared to be confined to the grey matter of the reticular substance. The thalamic nuclei were pigmented only in Grahl's case, and in none was there any abnormal pigmentation of the substantia nigrae.

The melanoblasts infiltrating the meninges were usually polygonal or oval and tended to be arranged in nests or sheets. The degree of pigmentation in the melanoblasts was very variable, but in all cases pigment-laden histiocytes (melanophores) were also seen. Perivascular cuffing and infiltration of the melanoblasts into the Virchow-Robin spaces was a characteristic of all cases. Of the 18 previously reported, the authors had considered that malignant change had occurred in all but 6 cases (Rokitansky, 1861 ; Binsack, 1912; Van Bogaert, 1948; Netherton, 1936; Maclachlan, 1914; Jütte, 1939). The malignant change may be diffuse or localized, and the criteria by which malignancy has been assessed vary. Thus infiltration of melanoblasts into the cerebral tissue has been taken to indicate malignant change in 7 cases (Wilcox, 1939; Grahl, 1906; Russell, 1949; Farnell and Globus, 1931; Berblinger, 1915; Lecouturier et al., 1939; Lua, 1914), while in one (Schlesinger and Schopper, 1912) there was infiltration of the optic chiasma. Evidence of cerebral infiltration was also seen in our Case 1 and has been taken together with cellular irregularity and mitotic activity as clear evidence of malignant change. Macroscopic examination alone may give a false impression of cerebral involvement, for although in many cases the pons and cerebellum have appeared pigmented the appearances have often been due to infiltration solely by melanin-containing histiocytes and not by melanoblasts. Indeed in our Case 2, pigmentation of the brain was entirely due to perivascular aggregations of pigment-laden macrophages, the meninges themselves showing little or no evidence of pigmentation and certainly no appreciable masses of naevoid cells. Infiltration solely by 
melanophores cannot be taken as evidence of malignancy. In this, one must carefully distinguish between infiltrating neoplastic cells and migrating melanophores that lie within Virchow-Robin spaces. The presence of pigment-laden macrophages in the perivascular spaces of the grey matter gives some support to the idea that there is normally a flow of cerebrospinal fluid in the direction of the brain tissue along these channels. In 4 cases the malignant change had occurred in a discrete form and given rise to a localized malignant melanoma of the meninges similar to the occipital tumour described in Case 1 above. In Björnboe's case the tumour had occurred in the meninges covering the convexity of the right cerebral hemisphere. A similar location was seen in Willis's case; in Obendorfer's case there was a cerebellar tumour and in Berblinger's case there was a pontine tumour. In Bouton's case there was neither infiltration of the brain by melanoblasts nor was there development of a discrete tumour, but he considered that the cellular irregularity of the meningeal melanoblasts was sufficiently marked to justify a diagnosis of malignant change in situ. In all the cases in which malignant change had taken place, as shown either by multifocal cerebral invasion or by localized tumour formation, the melanoblasts infiltrating the meninges showed a diffuse malignant change as shown by assumption of a spindle shape, by sheet formation, and by cellular and nuclear pleomorphism. In most cases, however, some areas still showed a benign picture in which the melanoblasts showed little pleomorphism and were arranged in clusters or nests. In our Case 1 the melanoblasts in the meninges of the cervical cord show a regular pattern with no evidence of malignancy, in contrast to the meninges of the cerebral hemispheres where the melanoblasts are spindle shaped, arranged in sheets, showing pleomorphism and cerebral invasion. Invasion of cerebral tissue appears to occur where the malignant changes are most marked, thus being further indication that the changes described are truly malignant.

Formes frustes of the syndrome undoubtedly occur, for 6 cases of benign melanosis of the meninges have been recorded in patients without skin lesions, and in whom the finding of meningeal melanosis was an incidental finding at necropsy (Kessler, 1937; Urbanek, 1943; Haferkamp and Risopatrón, 1955; Giampalmo, 1940; Erbslöh, 1956). One of these (Giampalmo) was associated with Sturge-Weber syndrome but in none was there any evidence of malignant change in the meningeal melanoblasts. In contrast to these a total of 76 cases of primary malignant melanoma of the meninges has been reported in patients with no skin lesions (Jütte, 1939;
Gibson, Burrows, and Weir, 1957; Kiel, Starr, and Hansen, 1961) following the first description of such a tumour by Virchow in 1859. All these cases have been fully studied at necropsy, and no evidence of primary tumour outside the central nervous system was found, nor was there any evidence of metastasis outside the central nervous system. These criteria, suggested by Winkelman, Gotten, and Silverstein (1936), are reasonable support for the diagnosis of primary meningeal melanoma; the original criteria of Lubarsch (1920) who denied such a diagnosis in the presence of any skin lesion, however small, or however apparently benign, are clearly too strict. In all the reported cases there has been a diffuse melanoblastic infiltration in the meninges in addition to the localized malignant tumour, and it is thought that in all cases the tumour has arisen from a preexisting meningeal melanosis. Thus Bouton (1958) has written that 'it is not unreasonable to assume that melanosis, diffuse in the majority of cases, always precedes the development of malignancy and must be considered as an essential pre-requisite for primary melanomas of the meninges'. It could be argued that this meningeal infiltration represents a spread throughout the meninges from the primary malignant tumour, but in many cases areas of clearly benign melanoblastic infiltration can be found, implying that pre-existing benign melanosis preceded the appearance of the malignant tumour.

It appears, therefore, that a total of 101 cases of meningeal melanosis has been recorded of which 18 were associated with pigmented skin naevi. Of these 101,88 have shown malignant change, the criteria for malignancy being either infiltration of the brain tissue from the meninges or the development of a localized malignant tumour. The condition must, therefore, be considered as being one with a high malignant potentiality.

Histogenesis and Nomenchature. Pigment cells are normally present in the pia-arachnoid. Thus Roca de Viñals, Elizalde Armendáriz, and Coma-Fabrés (1954) were able to find such cells in $85^{\circ}$ of normal adults studied at necropsy. Baader (1935) found such cells most prominently in the sulcus between pons and medulla, over the cerebral peduncles and over the base of the brain. Farnell and Globus (1931) have detected such cells in the meninges of children and infants and have also found them in a $5 \frac{1}{2}$-month foetus. There seems little doubt that these cells are the source of melanosis of the meninges and of any supervening tumours (Willis, 1960).

Throughout this paper the term 'melanosis' has been used to describe the pigmentation and infiltration of the meninges. Other names have been 
applied to this condition, e.g. melanoblastic hyperplasia (Gibson et al., 1957; Kiel et al., 1961), hamartomatous melanosis of the meninges (Willis, 1960); while Touraine (1949) has distinguished between 'melanism', in which there is an increased number of pigmented meningeal cells, 'melanosis' in which there is an accumulation of cells in nests, and 'melanomatosis' in which there are nodular formations of pigment cells in the meninges. It seems, however, that the distinction between the various grades proposed by Touraine is an arbitrary one and does not imply a valid distinction between various pathological processes, in so far as the histological picture in any given case of meningeal melanosis may vary considerably from one site to another in the meninges. The distinction between hamartoma, hyperplasia, and benign neoplasia is often blurred, and nowhere is this distinction less sharp than in meningeal melanosis. It would, therefore, be wiser to use the simple descriptive term 'melanosis', the use of such a term not carrying with it any histogenic connotations. Nevertheless, there is good evidence that the pia mater arises from the neural crest (Newth, 1951). There is also convincing evidence that melanoblasts arise from the neural crest in amphibians (Du Shane, 1948), birds, and certain mammals, i.e. mice, rats, and guinea-pigs (Rawles, 1948). Though no experimental proof exists in man for the origin of melanoblasts from the neural crest, it is probable that such is their origin. Taking into account that neuro-cutaneous melanosis is also associated with neurofibromatosis in a small number of cases and also with Sturge-Weber syndrome it appears reasonable to postulate that the condition is a congenital dysplasia of the neural crest.

\section{Summary}

The clinical and pathological findings in three children with neuro-cutaneous melanosis are desscribed, and the published reports on this condition reviewed. This lesion has a high malignant potentiality and usually causes death during early childhood. It is postulated that the condition is a congenital dysplasia of the neural crest.

We should like to thank Mr. R. T. Johnson for permission to quote the clinical details of Case 1: Professor W. I. C. Morris in whose department much of the work of preparing this paper was done; Mr. B. W. Figg for Figs. 1 to 7 ; and the Department of Medical Photography, The Royal Hospital, Sheffield for Fig. 8.

\section{REFERENCES}

Baader. O. (1935). Uber die Piamelanose. Z. Zellforsch., 22. 735. Berblinger, W. (1915). Ein Beitrag zur epithelialen Genese des Melanins. Virchow's Arch. path. Anat., 219, 328.

Binsack. A. (1912). Ein Fall von angeborene ausgedehnte Naevus Pigmentosus mit Pigment-Flecken in Gehirn. Thesis. Geissin.
Bịörnboe. M. (1934). Primāres Melanosarkom des Gehirns. massenhafte Naevi pigmentosi der Haut, ausgedehnte Neurofibromatose der Hautnerven. Frankfurt Z. Path.. 47. 363.

Bouton, J. (1958). Primary melanoma of the leptomeninges. J. clin. Path., 11, 122.

Du Shane. G. P. (1948). The development of pigment cells in vertebrates. In The Biology of Melanomas, ed. R. W. Miner. p. 1. Special publications of the New York Academy of Sciences. Vol. 4.

Erbslöh. F. (1956). Zur Pathologie der diffusen Pigmentgeschwülste im Meningealraum. Arch. Geschwulstforsch. 9. 103.

Farnell, F. J.. and Globus. J. H. (1931). Primary melanoblastosis of the leptomeninges and brain. Arch. Neurol. Psychiat. (Chic.). 25. 803 .

Giampalmo. A. (1940). Sulla malatia di Sturge e Weber. Pathologica, 32, 225.

Gibson. J. B., Burrows. D., and Weir. W. P. (1957). Primary melanoma of the meninges. J. Path. Bact.. 74, 419.

Grahl. F. (1906). Angeborener ausgedehnter Naevus pigmentosus in Verbindung mit Pigmentflecken im Gehirn. Beitr. path. Anat.. 39. 66.

Haferkamp. O.. and Risopatrón. L. S. (1955). Eigentümliche Melanose der Leptomeningen. Zbl. allg. Path. path. Anat.. 94. 274.

Jütte. H. (1939). Zwei Fālle von primārem Melanocytoblastom der Leptomeninx des Gehirns. Virchow's Arch. path. Anat.. 304, 296.

Kessler. M. M. (1937). Melanoblastosis and melanoblastoma: primary and secondary involvement of the brain. Amer. J. Cancer, 30. 19.

Kiel. F. W.. Starr. L. B.. and Hansen. J. L. (1961). Primary melanoma of the spinal cord. J. Neurosurg.. 18.616.

Lecouturier. R., Ley, J., Titeca, J., and van Bogaert. L. (1939). La mélanose néoplasique cérébro-cutanée. J. belge. Neurol. Psychiat., 39, 103.

Lua. M. (1914). Ueber pas primāre und des metastatische Melanosarkom des Zentralnervensystems. Arch. Psychiat. Nervenkr., 53, 895.

Lubarsch. O. (1920). Zur vergleichenden Pathologie der melanotischen Gewāchse. Med. Klin.. 16. 195.

Maclachlan. W. W. G. (1914). Extensive pigmentation of the brain associated with nevi pigmentosi of the skin. J. med. Res., 29.433.

Netherton. E. W. (1936). Extensive pigmented nevus associated with primary melanoblastosis of leptomeninges of brain and spinal cord. Arch. Derm. Syph. (Chic.), 33, 238.

Neubuerger, K. T., Daniels. L. E.. and Draper, P. A. (1943). Neurocytoblastoma of the brain and meningocutaneous melanomatosis. J. Neuropath. exp. Neurol.. 2. 140.

Newth. D. R. (1951). A remarkable embryonic tissue. Brit. med. J. 2. 96.

Obendorfer. C. (1903). Hydrocephalus congenitus. Pigment naevi; Endotheliom des Kleinhirns. Münch. med. Wschr. 50. 1235.

Rawles. M. E. (1948). Origin of melanophores and their role in development of color patterns in vertebrates. Physiol. Re:.. 28. 383.

Roca de Viñals. R.. Elizalde Armendáriz. C., and Coma-Fabrés. A. (1954). Tumores melánicos del S.N.C. A propósito de tres casos clinicos. Med. clin. (Barcelona). 22. 304.

Rokitansky. J. (1861). Ein ausgezeichneter Fall von Pigment-Ma! mit ausgebreiteter Pigmentirung der inneren Hirn- und Rückenmarkshāute. Allg. Wien. med. Ztg. 6. 113.

Russell. Dorothy S. (1949). Observations on the pathology of hydrocephalus. Spec. Rep. Ser. med. Res. Coun. (Lond.) No. 265.

Schlesinger. H., and Schopper. H. (1912). Primārer Melanosarkomatose des Gehirns und Rückenmarkes. Wien. klin. U'schr.. 25. 985.

Touraine. A. (1949). Les mélanoses neuro-cutances. Ann. Derm. Syph. (Paris). 8 ser., 9. 489.

Urbanek. K. (1943). Zur Kenntnis der gutartigen Melanome des Gehirns. Z. ges. Neurol. Psychiat., 175, 459.

Van Bogaert. L. (1948). La mélanose neurocutance diffuse hérédofamiliale. Bull. Acad. roy. Med. Belg.. 6th series, 13. 397.

Virchow, R. (1859). Pigment und diffuse Melanose der Arachnoides. Virchow's Arch. path. Anat., 16, 180.

Wilcox, J. C. (1939). Melanomatosis of the skin and central nervous system in infants. Amer. J. Dis. Child., 57, 391.

Willis. R. A. (1960). Pathology of Tumours. 3rd ed., p. 917. Butterworths. London.

Winkelman. N. W.. Gotten. N.. and Silverstein, A. (1936). Primary melanoblast tosis of the meninges. Arch. Neurol. Psychiat. (Chic.). 35. 919 . 